\title{
HUBUNGAN TEKSTUR SEDIMEN DAN KANDUNGAN BAHAN ORGANIK DENGAN KELIMPAHAN MAKROZOOBENTOS DI MUARA SUNGAI SILANDAK, SEMARANG
}

\author{
Relations of Sediment Textures and Organic Matter Contents \\ with Makrozoobentos Abundance in Silandak Estuary, Semarang \\ Dewi Meynita, Max Rudolf Muskananfola *), Sri Sedjati
}

Program Studi Manajemen Sumberdaya Perairan, Departemen Sumberdaya Akuatik

Fakultas Perikanan dan Ilmu Kelautan, Universitas Diponegoro

Jl. Prof. Soedarto, SH, Tembalang, Semarang, Jawa Tengah - 50275, Telp/Fax +6224 7474698

Email :dewi.meynita@gmail.com

\begin{abstract}
ABSTRAK
Muara Sungai Silandak merupakan salah satu subsistem drainase wilayah Semarang Barat yang bermuara ke teluk Semarang.Muara merupakan tempat akumulasi buangan limbah domestik dan pabrik. Dilakukannya reklamasi pantai pada bagian hilir Muara Silandak dapat menyebabkan sedimentasi yang akan mempengaruhi keberadaan makrozoobentos. Tujuan dari penelitian ini adalah mengetahui tekstur sedimen, kandungan bahan organik dan kelimpahan makrozoobentos.Materi yang digunakan dalam penelitian ini adalah sampel sedimen dan sampel makrozoobentos pada setiap stasiun yang berlokasi di muara sampai pesisir Pantai Maron.Penelitian ini dilakukan dengan sampling acak atau Random Sampling dengan empat stasiun.Pada setiap stasiun terdapat tiga titik sampling, sampel sedimen dan makrozoobentos diambil pada setiap titik kemudian dikomposit perstasiun.Sampling dilakukan pada interval waktu dua minggu dengan tiga kali pengulangan.Hasil analisis tekstur sedimen pada stasiun I memiliki tekstur liat sedangkan stasiun II, III dan IV memiliki tekstur lempung liat berpasir. Hasil kandungan bahan organik pada stasiun I,II, III dan IV sebesar 19,33\%, 15,20\%, 13,40\% dan 10,67\%. Sedangkan kelimpahan makrozoobentos yang didapatkan stastiun I sebesar 652 ind/m3, stasiun II 696 ind/m3, stasiun III 783 ind/m3 (tertinggi) dan stasiun IV 261 ind/m3 dengan katagori indeks keanekaragaman belum tercemar dan tidak adanya jenis yang mendominasi.
\end{abstract}

Kata kunci: Tekstur Sedimen, Kandungan Bahan Organik, Kelimpahan Makrozoobentos, Muara Sungai Silandak Semarang.

\begin{abstract}
Silandak Estuary is one of the subsystem drainage areas in West Semarang that flow into the bay of Semarang. The estuary is a place of accumulation of domestic sewage and factories. Coastal reclamation at the downstream estuary Silandak causing sedimentation that will affect the existence of macrozoobenthos. The purpose of this research was to know the sediment texture, organic matter content and abundance of macrozoobenthos. The material used in this research is the sediment samples and samples of macrozoobenthos at any station located at the estuary to the coast of Maron. The research used random sampling with four stations. At each station there are three sampling points, samples of sediment and makrozoobentos taken at any point which then composite sample at each station. The sampling was done with time interval of two weeks with three repetitions. The results of the sediment texture at the station I has the texture of clay while the station II, III and IV have a texture of sandy clay loam. The results of the organic material content at stations I, II, III and IV is amounted 19,33\%, 15,20\%,13,40\% and 10,67\% and while abundance of makrozoobentos at station I are 652 ind/m3, station II $696 \mathrm{ind} / \mathrm{m3}$, station III $783 \mathrm{ind} / \mathrm{m3}$ (higher) and station IV $261 \mathrm{ind} / \mathrm{m} 3$ with a diversity index categories clean water zone and not found the dominant species.
\end{abstract}

Keywords: Sediment Textures, Organic Matter Contents, Abundance of Makrozoobentos, Silandak Estuary Semarang.

*)Penulis penanggungjawab 


\section{PENDAHULUAN}

Muara sungai merupakan bagian hilir dari sungai yang berhubungan langsung dengan laut.Permasalahan di muara sungai dapat ditinjau di bagian mulut sungai (river mouth) dan muara.Mulut sungai adalah bagian paling hilir dari muara sungai yang langsung bertemu dengan laut (Sari et al, 2012). Menurut Maslukah (2013), muara memiliki ciri yaitu daerah yang mempunyai kekeruhan cukup tinggi yang disebabkan karena adanya masukan air sungai dan resuspensi sedimen. Di perairan muara dimana terjadi pertemuan massa air tawar (bersalinitas rendah dan mempunyai kekuatan ionik lemah) dengan air laut (bersalinitas tinggi dan mempunyai kekuatan ionik lebih tinggi) mengakibatkan terjadinya pengendapan karena gaya gravitasi.sedimen dapat digunakan sebagai indikator pencemaran karena perannya sebagai 'sink' bagi bahan-bahan pencemar di daratan.

Salah satu komunitas biologis atau organisme yang merasakan langsung pengaruh bahan pencemar tersebut adalah benthos, karena hewan ini hidupnya relatif menetap. Makrozoobenthos merupakan kelompok hewan yang memiliki peranan penting dalam ekosistem sebagai organisme kunci dalam jaring makanan karena makrozoobenthos menjadi bahan makanan bagi organisme lain. Bahan organik merupakan sumber makanan bagi biota laut yang pada umumnya terdapat pada substrat dasar sehingga ketergantungannya terhadap bahan organik sangat besar (Hawari et al., 2013).

Muara Sungai Silandak merupakan salah satu drainase Kota Semarang wilayah barat yang sudah mengalami normalisasi muara. Keadaan sungai pada bagian hulu yang mengalami pendangkalan akan menyebabkan debit atau limpasan air laut masuk kedalam sungai. Perlunya pengelolaan terhadap muara sungai yang menjadi bagian dari tempat pembuangan dan akumulasi bahan pencemar yang berasal dari sungai, menyebabkan daerah tersebut memiliki keragaman biota yang dapat dijadikan sebagai indikator perairan.Kandungan bahan organik yang ada diperairan merupakan sumber makanan bagi biota yang berasosiasi tetapi dapat menjadi toksik apabila konsentrasi tinggi.

Tujuan dari penelitian ini adalah sebagai berikut;

1. Mengetahui tekstur sedimen dan kandungan bahan organik di Muara Sungai Silandak;

2. Mengetahui struktur komunitas kelimpahan dan indeks keanekaragaman makrozoobentos;

3. Mengetahui hubungan antara sedimen dan kandungan bahan organik dengan kelimpahan makrozoobentos.

\section{MATERI DAN METODE PENELITIAN}

\section{A. Materi Penelitian}

Materi dalam penilitian ini adalah tekstur sedimen, bahan organik dan makrozoobentos pada substrat dasar di muara Sungai Silandak.Makrozoobentos dilakukan perhitungan indeks keanekaragaman dan indeks keseragaman.Sedangkan parameter pendukung seperti suhu, salinitas, kedalaman, kecerahan, arus, pH dan DO (Dissolve Oxigen) dilakukan pengukuran in situ.Alat yang digunakan dalam penelitian ini adalah grab, secchi disc, kertas $\mathrm{pH}$, refraktometer, termometer air raksa, oven, furnace, gelas beker, timbangan elektrik, cawan petri, Erlenmeyer, botol BOD, saringan bentos dan gelas ukur. Bahan yang digunakan yaitu formalin, rose ben

\section{B. Metoda Penelitian}

Metode penelitian dalam pengambilan sampel yang dilakukan dilapangan dengan sampling acak (Random sampling).Random sampling yang digunakan berdasarkan pertimbangan lokasi penelitian di Muara Sungai Silandak, Semarang.Penentuan lokasi sampling dilakukan pada 4 stasiun yang berbeda yaitu stasiun I pada bagian perbatasan sungai dengan muara, stasiun II berada di muara, stasiun III berada di bagian mulut muara dan stasiun IV berada di Pantai Maron. Jarak antara tiap stasiun adalah \pm 300 meter dan pada stasiun IV jarak pengambilan sampel tiga meter dari pesisir pantai.

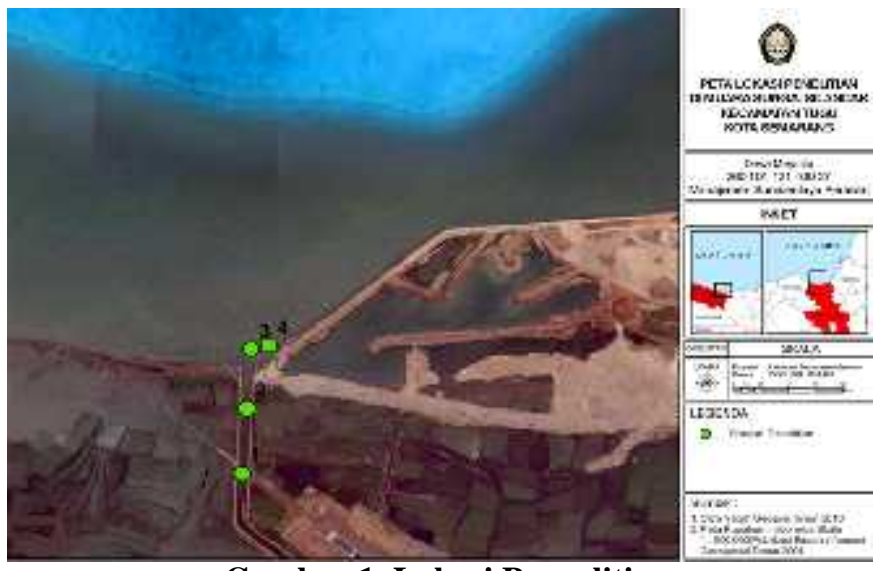

Gambar 1. Lokasi Penenlitian

${ }^{(}$Copyright by Management of Aquatic Resources (MAQUARES) 


\section{Teknik Pengambilan Sampel}

Pengambilan sedimen dilakukan pada permukaan sedimen bagian atas yang digunakan untuk pengukuran tekstur sedimen dan bahan organik. Pengambilan sampel makrozoobentos dengan menggunakan grab pada setiap titik sampling. Sampel bentos yang didapatkan dimasukkan kedalam botol sampel dan diawetkan dengan formalin $4 \%$.

\section{Analisis Laboratorium}

\section{a. Analisis tekstur sedimen}

Analisa pengukuran tekstur sedimen dengan analisa butir sedimen dan pemipetan menggunakan metode (Buchanan, 1971).

- Fraksi pasir

Didapatkan dari hasil penimbangan sampel sedimen yang tidak lolos pada masing-masing tingkat saringan yang berbeda kemudian di jumlahkan (berat total) dan fraksi lumpur Didapatkan dari hasil pemipetan dengan waktu yang berbeda pada masing-masing sampel yang telah dioven kemudian ditimbang beratnya lalu di konversikan.

$$
\begin{aligned}
& \text { Presentase fraksi pasir }(\%) \quad=\frac{\text { verat pusir }(g r)}{2 \text { gr })} \times 100 \% \\
& \text { Presentase fraksi lumpur }(\%) \quad=\frac{\text { Derat total } / \text { raksilumpur }[\mathrm{gr})}{2 \mathrm{gr}} \times 100 \% \\
& \text { Presentase fraksi liat }(\%) \quad=100 \%-\% \text { fraksi pasir }-\% \text { fraksi lumpur }
\end{aligned}
$$

\section{b. Analisis bahan organik pada sedimen}

Analisa menggunakan prinsip gravimetrik dalam Buchanan, 1971.

Keterangan :

$$
\text { Bahan organik }=\frac{(W t-C)-(W a-C)}{W t-C} \approx 100 \%
$$

$\mathrm{Wt}=$ berat total (crucible + sampel) sebelum dibakar

$\mathrm{Wa}=$ berat total (crucible + sampel) setelah dibakar

$\mathrm{C}=$ berat crucible kosong

\section{c. Analisis makrozoobentos}

- Kelimpahan Individu

Kelimpahan makrozoobentos dihitung berdasarkan jumlah individu persatuan luas $\left(\mathrm{ind} / \mathrm{m}^{3}\right)$ dengan menggunakan rumus Shannon-Wiener (Dwirastina, 2013):

Dimana :

$$
\mathbf{K}=\frac{\mathrm{Q}}{\mathrm{e}}
$$

Y : Indeks kelimpahan jenis (Jumlah Individu) (ind $/ \mathrm{m}^{3}$ )

a : Jumlah makrozoobenthos yang tersaring (ind)

b : Volume grab $x$ Jumlah Ulangan

Volume grab $: 1 / 2 \times \pi \times \mathrm{r}^{2} \times \mathrm{h}$

- Kelimpahan Relatif

Kelimpahan relatif dihitung dengan rumus Shannon-Wiener (Odum, 1971)

Dimana :

$$
\mathbf{K R}=(\mathbf{n i} / \mathbf{N})^{2} \times 100
$$

KR : Kelimpahan relatif

ni :Jumlah individu setiap jenis

$\mathrm{N}$ : Jumlah seluruh individu

- Indeks Keanekaragaman

Indeks keanekaragaman dihitung dengan rumus Shannon-Wiener (Gray dan Elliot, 2009)

$$
H^{\prime}=-\sum_{i=1}^{s}\left(\frac{n \bar{i}}{N}\right) \ln \left(\frac{n \bar{i}}{N}\right)
$$


Dimana :

H' : Indeks keanekaragaman jenis

ni : Jumlah individu jenis

$\mathrm{N}$ : Jumlah total individu

Kisaran indeks keanekaragaman berdasarkan pengamatan yang dilakukan di perairan mengalir oleh Wilhm (1970) yang terdapat pada Averett (1981), bahwa:

$\begin{array}{ll}\mathrm{H}^{\prime}=0-10 \text { dan } 0-5 & \text { : Belum Tercemar } \\ \mathrm{H}^{\prime}=3 \text { dan } 4 & \text { : Normal } \\ \mathrm{H}^{\prime}=<1 & \text { : Tercemar Bahan OrganikIndeks Keseragaman }\end{array}$

- Indeks keseragaman dihitung dengan menggunakan rumus Evennes-Indeks (Gray dan Elliot, 2009)

Dimana :

$$
E=\frac{H^{r}}{\ln \boldsymbol{S}}
$$

E : Indeks keseragaman jenis

$\mathrm{H}^{\prime} \quad$ : Indeks keanekaragaman jenis

S : Jumlah jenis organisme

Dimana menurut Krebs (1978) :

$\mathrm{E}<0,4 \quad$ : tingkat keseragaman populasi kecil

$0,4<\mathrm{e}<0,6 \quad$ : tingkat keseragaman populasi sedang

$0,6<\mathrm{e}<1 \quad$ : tingkat keseragaman populasi tinggi

- Indeks dominansi (D)

Indeks domonansi dihitung untuk mengetahui ada atau tidaknya spesies yang mendominasi (Gray dan Elliot, 2009).

Dimana :

$$
\mathbf{D}=(\mathbf{n i} / \mathbf{N})^{2}
$$

C : Indeks dominansi

ni : Jumlah individu setiap jenis

$\mathrm{N}$ : Jumlah total individu

\section{HASIL DAN PEMBAHASAN}

\section{A. Hasil}

Hasil pengukuran tekstur sedimen yang didapat berdasarkan rata-rata tiap stasiun yang dilakukan memiliki nilai persentase kandungan pasir, lumpur dan liat yang tersaji pada Tabel 1.

Tabel 1. Hasil Pengukuran Tekstur Sedimen

\begin{tabular}{ccccc}
\hline \multirow{2}{*}{ Stasiun } & \multicolumn{3}{c}{ Fraksi Sedimen } \\
\cline { 2 - 5 } & Pasir (\%) & Lumpur (\%) & Liat (\%) & Tekstur \\
\hline I & 38,25 & 1,00 & 60,74 & Liat \\
II & 66,22 & 0,47 & 33,32 & Lempung Liat Berpasir \\
III & 76,45 & 0,40 & 23,15 & Lempung Liat Berpasir \\
IV & 79,55 & 0,28 & 20,17 & Lempung Liat Berpasir \\
\hline
\end{tabular}

Hasil pengukuran kandungan bahan organik sedimen yang dilakukan pada setiap pengulangan mendapatkan hasil yang tersaji pada Tabel 2 .

Tabel 2. Hasil Pengukuran Kandungan Bahan Organik

\begin{tabular}{ccccc}
\hline \multirow{2}{*}{ Stasiun } & \multicolumn{2}{c}{ Nilai Kandungan Bahan Organik (\%) } & \multirow{2}{*}{ rata-rata } \\
\cline { 2 - 4 } & 26-Mar-16 & 9-Apr-16 & 23-Apr-16 & 19,33 \\
I & 33 & 13 & 12 & 15,20 \\
II & 24 & 11 & 10,6 & 13,40 \\
III & 11 & 10,2 & 19 & 10,67 \\
IV & 10 & 8 & 14 &
\end{tabular}


Hasil yang diperoleh dari perhitungan kelimpahan makrozoobentos didapatkan 55 individu dengan 15 genus pada 3 klas yaitu klas polychaeta terdapat 6 genus, gastropoda 4 genus dan bivalvia terdapat 5 genus. Hasil yang didapatkan pada stasiun I dengan kelimpahan individu $652 \mathrm{ind} / \mathrm{m}^{3}$, stasiun II $696 \mathrm{ind} / \mathrm{m}^{3}$, stasiun III $783 \mathrm{ind} / \mathrm{m}^{3}$ dan stasiun IV sebesar $261 \mathrm{ind} / \mathrm{m}^{3}$. Nilai struktur komunitas dengan nilai indeks keanekaragaman, keseragaman dan dominasi tersaji pada Tabel 3.

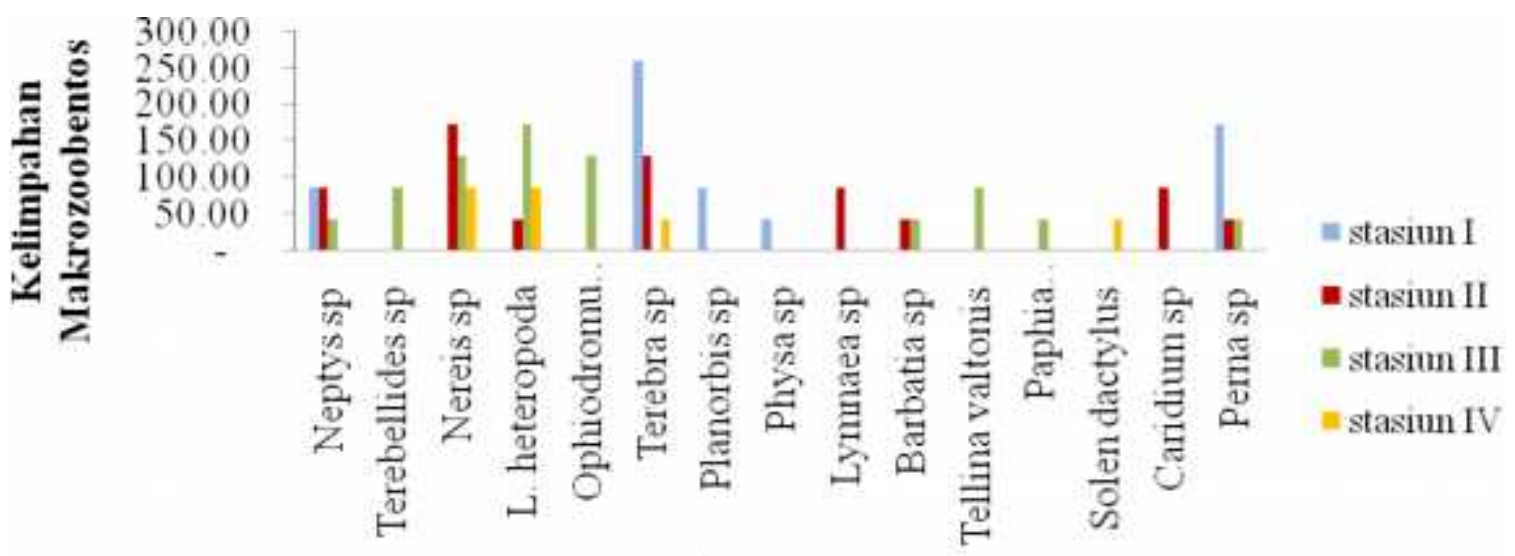

\section{Genus}

Gambar 2. Kelimpahan Makrozoobentos

Tabel 3. Indeks Keanekaragaman, Keseragaman dan Dominasi

\begin{tabular}{|c|c|c|c|c|c|c|}
\hline Stasiun & $\mathbf{H}^{\prime}$ & Katagori $^{(a}$ & $\mathbf{e}$ & Katagori $^{(b}$ & D & Katagori \\
\hline I & 1,437 & $\begin{array}{l}\text { Belum } \\
\text { tercemar }\end{array}$ & 0,893 & Tinggi & 0,271 & $\begin{array}{l}\text { Tidak ada } \\
\text { dominasi }\end{array}$ \\
\hline II & 1,960 & $\begin{array}{l}\text { Belum } \\
\text { tercemar }\end{array}$ & 0,943 & Tinggi & 0,156 & $\begin{array}{l}\text { Tidak ada } \\
\text { dominasi }\end{array}$ \\
\hline III & 2,062 & $\begin{array}{l}\text { Belum } \\
\text { tercemar }\end{array}$ & 0,938 & Tinggi & 0,142 & $\begin{array}{l}\text { Tidak ada } \\
\text { dominasi }\end{array}$ \\
\hline IV & 1,330 & $\begin{array}{l}\text { Belum } \\
\text { tercemar }\end{array}$ & 0,959 & Tinggi & 0,278 & $\begin{array}{l}\text { Tidak ada } \\
\text { dominasi }\end{array}$ \\
\hline
\end{tabular}

Berdasarkan hasil yang didapatkan menggunakan uji analisis korelasi Pearson dengan bantuan SPSS, untuk mengetahui hubungan tekstur sedimen (pasir, lumpur dan liat) dengan kandungan bahan organik dan kelimpahan Makrozoobentos dengan hasil sebagai berikutdapat dilihat pada Tabel 4 dan 5:

\begin{tabular}{lcc}
\hline \multicolumn{1}{c}{ Analisa Uji } & $r$ (Korelusi) & Sig. (2-tailed) \\
\hline Pasir dengan Bahan Organik & $-0,766$ & $0,004^{* *}$ \\
Lumpur dengan Bahan Organik & 0,742 & $0,006^{* *}$ \\
Liat dengan Bahan Organik & 0,768 & $0,004^{* *}$ \\
\hline
\end{tabular}

Tabel 4. Hasil Korelasi antara Tekstur Sedimen dengan Kandungan Bahan Organik

Tabel 5. Hasil Korelasi antara Tekstur Sedimen dengan Kelimpahan Makrozoobentos

\begin{tabular}{lcc}
\hline \multicolumn{1}{c}{ Analisa Uji } & $r$ (Karelusi) & Sig. (2-tailed) \\
\hline Pasir dengan Kelimpahan Makrozoobentos & $-0,668$ & $0,018^{* *}$ \\
Lumpur dengan Kelimpahan Makrozoobentos & 0,617 & $0,03^{* *}$ \\
Liat dengan Kelimpahan Makrozoobentos & 0,668 & $0,018^{* *}$
\end{tabular}


Berdasarkan hasil hubungan dari kandungan bahan organik dengan kelimpahan makrozoobentos yang didapatkan melalui analisis data menggunakan korelasi Pearson didapatkan hasil sebagai berikut, tersadi pada Tabel 6:

Tabel 6. Hasil Korelasi antara Kandungan Bahan Organik dengan Kelimpahan Makrozoobentos

\begin{tabular}{ccc}
\hline Analisa Uji & $r$ (Korelusi) & Sig. (2-tailed) \\
\hline Kandungan Bahan Organik dengan Kelimpahan Makrozoobentos & 0,682 & $0,015^{* *}$ \\
\hline
\end{tabular}

\section{B. Pembahasan}

Pada stasiun I tekstur liat sangat dominan sebesar 60,74\%, letak stasiun I yang berada di antara muara dan sungai menjadikan substrat dasarnya liat. Stasiun II yang berada tepat di Muara Silandak memiliki fraksi liat sebesar 33,32\%. Pasir sangat dominasi dan keadaan pantai yang mengalami reklamasi menjadikan kandungan pasir sangat tinggi.Berdasarkan hasil yang didapat dari penelitian sebelumnya menyatakan adanya perbedaan kandungan tekstur pada lokasi yang terkena reklamasi dan tidak terkena reklamasi. Didapatkan nilai sebesar $83,56 \%$ untuk daerah yang terkena reklamasi dan $77 \%$ pada daerah yang belum terkena reklamasi. Daerah tersebut yang berlokasi di Pantai Marina, Semarang.Kandungan bahan organik pada sedimen memiliki kisaran sebesar 10,67\%-19,33\%. Hal ini terdapat dalam pernyataan Reynold (1971) dalam Kinasih (2015), yang mengklasifikasikan kandungan bahan organik dalam sedimen dengan nilai $7 \%$ - 17\% termasuk tingkatan sedang dan tingkatan tinggi sebesar 17\% - 35\% maka dapat dikatakan bahwa kandungan bahan organik pada Muara Sungai Silandak termasuk kedalam kriteria tinggi. Hasil kandungan bahan organik pada muara Sungai Silandak dapat dibandingkan dengan kandungan bahan organik yang ada di muara sungai Tuntang dengan hasil sebesar $6,86 \%-13,20 \%$. Kandungan bahan organik tinggi dipengaruhi oleh jenis substrat seperti di stasiun I yang berlokasi di sungai dekat muara dengan jenis sedimen liat.Berdasarkan penelitian yang dilakukan di Muara Silandak dan Muara Siangker oleh Lufiana (2016), Muara Silandak memiliki kandungan nitrat dan fosfat pada bagian muara yaitu $0,90 \mathrm{mg} / \mathrm{l}$ dan $0,88 \mathrm{mg} / \mathrm{l}$ angka tersebut sudah melebihi ambang batas baku mutu untuk perairan. Menurut keputusan Menteri Lingkungan Hidup Nomer 51 Tahun 2004 tentang baku mutu air laut dan biota laut untuk nitrat $0,008 \mathrm{mg} / \mathrm{l}$ dan fosfat $0,015 \mathrm{mg} / \mathrm{l}$. Diperkuat oleh Risamasu et al. (2011), konsentrasi nitrat akan lebih tinggi di dekat dasar perairan karena dipengaruhi oleh sedimen.

Kelimpahan makrozoobentos pada satuan ind berbanding volume total $\left(\mathrm{m}^{3}\right)$, pada stasiun I,II,III dan IV berjumlah $652 \mathrm{ind} / \mathrm{m}^{3}, 696 \mathrm{ind} / \mathrm{m}^{3}, 783 \mathrm{ind} / \mathrm{m}^{3}$ dan $261 \mathrm{ind} / \mathrm{m}^{3}$.Keberadaan bentos juga dipengaruhi oleh jenis substrat dan kedalaman perairan. Makrozoobentos merupakan suatu indikator pencemaran pada perairan karena sifat bentos yang menetap dan cara makan bentos dengan filter feeding dan deposit feeding. Makrozoobentos dapat bertahan pada kondisi perairan yang kurang baik maka disebut sebagai bioindikator, bahan pencemar yang terakumulasi dalam tubuh bentos dapat menandakan seberapa berat pencemaran dalam perairan tersebut.

Makrozoobentos memiliki kisaran toleransi tertentu terhadap kondisi ekologi dengan seberapa jauh keberhasilannya mengembangkan mekanisme adaptasi.Hal tersebut memungkinkan faktor-faktor ekologi mengatur komposisi dan ukuran komunitas bentik.Dalam menghadapi perubahan kondisi lingkungan di habitatnya, bentik telah mengembangkan berbagai bentuk adaptasi morfologi.Adaptasi morfologi yang dimaksud adalah adaptasi ukuran tubuh, adaptasi bentuk tubuh, penyederhanaan organ dan memperkuat dinding tubuh serta mengembangkan alat pelekat (Hadiputra dan Alia, 2013).

Hasil dari uji korelasi Pearson antara tekstur sedimen dengan kandungan bahan organik dengan nilai korelasi pada fraksi pasir dengan bahan organik sebesar -0,766, fraksi lumpur dengan bahan organik dengan nilai sebesar 0,742 dan fraksi liat dengan bahan organik sebesar 0,768. Hal ini di perkuat oleh Misbahudin dan Hasan (2013), nilai korelasi kuat pada koefesien korelasi dengan nilai $0,70 \leq \mathrm{r} \leq 0,90$. Adanya nilai korelasi yang negative terjadi pada hubungan fraksi pasir dengan bahan organik menyatakan bahwa hubungan yang terjadi bertolak belakang, yaitu apabila kandungan pasir meningkat maka kandungan bahan organik akan menurun dan sebaliknya. Hubungan tekstur sedimen dengan kelimpahan makrozoobentos didapatkan hasil korelasi Pearson dengan nilai korelasi negative pada fraksi pasir sebesar -0,668 dan korelasi positif pada fraksi lumpur dan liat dengan nilai sebesar 0,617 dan 0,668. Hal ini diperkuat oleh Misbahudin dan Hasan (2013), nilai korelasi (r) $0,40 \leq \mathrm{r} \leq 0,70$ menunjukan adanya hubungan yang substansial atau cukup. Menurut Lubis et al. (2013), faktor yang mempengaruhi keberadaan makrozoobentos adalah faktor fisika, kimia lingkungan diantaranya penetrasi cahaya yeng berpengaruh terhadap suhu air, kandungan unsur kimia seperti pH dan DO. Kelimpahan makrozoobentos bergantung pada toleransi atau sensitifitasnya terhadap perubahan lingkungan dan setiap jenis memiliki respon berbeda. Berdasarkan hubungan kandungan bahan organik dengan kelimpahan makrozoobentos pada uji korelasi Pearson dengan nilai korelasi positif sebesar 0,682 Hal ini diperkuat oleh Misbahudin dan Hasan (2013), nilai korelasi (r) 0,40 $\leq \mathrm{r} \leq 0,70$ menunjukan adanya hubungan yang substansial atau cukup. Faktor lain yang mempengaruhi dari analisis kandungan bahan organik dengan kelimpahan. Karena keberadaan makrozoobentos bergantung terhadap kandungan organik pada substrat. Menurut Yeanny (2007), kandungan

${ }^{\circledR}$ Copyright by Management of Aquatic Resources (MAQUARES) 
organik substrat memeberikan pengaruh terhadap kehidupan makrozoobentos karena habitat bentos yaitu terdapat di substrat dasar perairan.

Hubungan yang terjadi antara tekstur sedimen dengan kandungan bahan organik dan kelimpahan makrozoobentos memiliki nilai signifikasi < 0,05. Dan pada hubungan kandungan fraksi liat dengan bahan organik yang ada di perairan muara sunagi Betah Walang, Demak memilki nilai korelasi 0,24 dapat dikatakan korelasi tersebut rendah dibandingkan dengan hubungan fraksi liat dengan kandungan bahan organik di muara sungai Silandak sebesar 0,768 termasuk kedalam nilai korelasi yang kuat.

\section{KESIMPULAN}

Berdasarkan hasil penelitian yang telah dilakukan, dapat disimpulkan bahwa:

1. Tekstur sedimen di Muara Silandak pada stasiun I yaitu bertekstur liat dan stasiun II,III dan IV bertekstur lempung liat berpasir. Nilai persentase fraksi pasir sebesar 38,25\%-88,10\%. Fraksi lumpur memiliki nilai persentase sebesar 0,16\%-1,00\% sedangkan pada fraksi liat 20,17\% - 60,74\%. Kandungan bahan organik di Muara Silandak memiliki nilai 10,67\% - 19,33\% dengan kandungan bahan organik tertinggi pada stasiun I;

2. Kelimpahan makrozoobentos pada Muara Silandak yang didapat yaitu klas polychaeta 5 genus, gastropoda 4 genus dan bivalve 6 genus dengan jumlah individu 55. Struktur komunitas makrozoobentos didapatkan nilai kelimpahan pada stasiun I $652 \mathrm{ind} / \mathrm{m}^{3}$, stasiun II $696 \mathrm{ind} / \mathrm{m}^{3}$, stasiun III tertinggi sebesar $783 \mathrm{ind} / \mathrm{m}^{3} \mathrm{dan}$ stasiun IV $261 \mathrm{ind} / \mathrm{m}^{3}$. Pada nilai indeks keanekaragaman makrozoobentos masih dalam katagori belum tercemar;

3. Hubungan antara tekstur sedimen dengan bahan organik memiliki hasil korelasi yang kuat. Hubungan tekstur sedimen dengan kelimpahan makrozoobentos memiliki hasil korelasi yang cukup dan hasil dari hubungan antara bahan organik dengan kelimpahan makrozoobentos memiliki hasil korelasi yang cukup.

\section{UCAPAN TERIMAKASIH}

Ucapan terimakasih ditujukan kepada Prof. Dr. Ir. Sahala Hutabarat, M.Sc., Drs. Ign Boedi Hendrarto,MSc, Ph.D., Ir. Anhar Solichin, M.Si., Dr. Ir. Pujiono Wahyu P., MS., yang telah memberikan masukan, kritik dan saran yang sangat berarti bagi penulis.

\section{DAFTAR PUSTAKA}

Buchanan, J. B. 1971. Sediment Analisis.In Holme and McLntryre.Method for Study of Marine Benthos.Blackhel Scientific Publication. London.

Dwirastina, M. 2013. Teknik Pengambilan dan Identifikasi Bentos Kelas Oligochaeta di Daerah Riau Pekanbaru.Balai Riset Perikanan Perairan Umum, Jurnal Perikanan 11 (2): 41-44.

Gray, J.S dan M. Elliott. 2009. Biology of Marine Sediments. Oxford New York. Oxford University Press.

Hadiputra, M.A dan A. Damayanti. 2013. Kajian Potensi Makrozoobentos Sebagai Bioindikator Pencemaran Logam Berat Tembaga $(\mathrm{Cu})$ di Kawasan Ekosistem Mangrove Wonorejo Pantai Timur Surabaya.[Jurnal]. Prosiding Seminar Nasional Manajemen Teknologi XVIII. Intitut Teknologi Sepuluh Nopember.

Hawari, A, B Amin dan Efriyeldi.2013. Hubungan Antara Bahan Organik Sedimen Dengan Kelimpahan Makrozoobenthos Di Perairan Pantai Pandan Provinsi Sumatera Utara.

Iban, S. 2010. Dampak Sedimentasi Terhadap Kualitas Perairan. http://id.scribd.com/doc/27063850/DampakSedimentasi-Terhadap-Kualitas-Perairan. Akses tanggal 16 Juni 2016

Kinasih, A. R. N., P.W. Purnomo dan Ruswahyuni. 2015. Analisis Hubungan Tekstur Sedimen dengan Bahan Organik, Logam Berat ( $\mathrm{Pb}$ dan $\mathrm{Cd}$ ) dan Makrozoobentos di Sungai Betahwalang, Demak. Jurnal Maquares. 4(3): 99-107.

Lubis, M. S, M. Basyuni dan A. Suryanti. 2012. Keanekaragaman dan Kelimpahan Makrozoobentos di Sungai Naborsahan Kabupaten Toba Samosir Sumatera Utara.

Lufiana, T., Haerudin dan C. A’in.2016. Analisis Beban Pencemaran dan Indeks Kualitas Air Sungai Silandak dan Sungai Siangker, Semarang.[Skripsi]. Program Studi Manajemen Sumberdaya Perairan. Departemen Sumberdaya Akuatik, Fakultas Perikanan dan Ilmu Kelautan, Universitas Diponegoro. Semarang.

\footnotetext{
${ }^{\circledR}$ Copyright by Management of Aquatic Resources (MAQUARES)
} 
Maslukah, L. 2013. Hubungan antara Konsentrasi Logam Berat Pb, Cd, Cu, Zn dengan Bahan Organik dan Ukuran Butir dalam Sedimen di Estuari Banjir Kanal Barat, Semarang. Buletin Oseanografi Marina, $2: 55-62$.

Misbahudin, Iqbal Hasan, (2013), Analisis Data Penelitian Dengan Statistik, Jakarta, Bumi Aksara.

Risamasu, F.J.L dan H.B. Prayitno.2011. Kajian Zat Hara Fosfat, Nitrit, Nitrat dan Sillkat di Perairan Kepulauan Matasiri, Kalimantan Selatan. Jurnal Ilmu Kelautan. 16(3): 135-142.

Roswaty, S., M. R. Muskananfola, dan P. W. Purnomo. 2014. Tingkat Sedimentasi Di Muara Sungai Wedung Kecamatan Wedung, Demak, Jurnal maquares. Universitas Diponegoro 3(2) : 129-137.

Taqwa, A. 2010.Analisis Produktifitas Primer Fitoplankton dan Struktur Komunitas Fauna Makrozoobentos Berdasarkan Kerapatan Mangrove di Kawasan Mangrove dan Bekantan Kota Tarakan, Kalimantan Timur.[Thesis]. Magister Manajemen Sumberdaya Pantai, Universitas Diponegoro.

Yeanny, M. S. 2007. Keanekaragaman Makrozoobenthos di Muara sungai Belawan, Jurnal Biologi. Departemen Biologi, Fakultas MIPA, Universitas Sumatera Utara. Medan. 2(2): 3741. 